specimens of pyrites in collections was discussed. Calcite, a clear scalenohedral crystal, probably from Iceland, consists of a combination

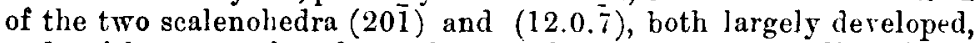
and with an angle of $4 \frac{1}{2}$ degrees between corresponding faces. Epidote, a crystal, probably from Ala, Piedmont, closely resembling in appearance the yellow prismatic crystals of anatise, carries a minute face (134) (Dana's orientation) in addition to twenty other crystalforms.

Dr. G. F. Herbert Smith: "A Curious Crystal from the Binnental." The crrstal, which was found with a few loose sartorite crystals in the Trechmann Collection, is twinned and tabular in habit, and shows signs of corrosion. The symmetry is peculiar, since, although a face occurs at right angles to the prism edge, it is neither a plane nor a pole of symmetry, and the erystal appears to represent a new species of sulpharsenite.

\title{
COERESPONDENOE.
}

\section{THE TERTIARY GEOLOGY OF DEVON AND CORNWALL.}

Sra,-Referring to your reviewer's remarks in the November number, p. 521, on an inquiry into the recent riews relative to "The Tertiary Geology of Devon and Cornwall", may I be allowed a few lines to meet the objections that the "argument concerning the age of the limestone caverns is not very clear, and its bearing on the point at issue is not obvious".

The point at issue is the submergence of the peninsula during the Pliocene era as predicated by the platform theory. Of the seren standpoints from which the theory was considered, the caverns were taken as one contributing important controrerting evidence. It was shown that caverns are almost entirely formed by solution of the rock, an immeasurably slow process, requiring geological ages to form these large subterranean hollows. It was also pointed out that the lowest deposits in the Devon caverns are glacial formations (surface material swept through the swallow-holes into the lowest depths during extraordinary climatic conditions) that determine the pre-Glacial existence of the cavern. It follows that the human and animal relies found in this deposit (the breccia) must have been of Pliocene origin. Now as the elevation of the caverns abore the sea-level during their whole existence is unquestioned, and when the many ages taken in the formation of the similar Derby and Yorkshire caverns are put in comparison, it does not appear consistent with the character of the facts to assign the formation of the Deron carerns to the comparatively short geological period that mus be implied to terminate the Pliocene era, as subsequent to the rast space of time drawn upon that era, wlich the enormous results embraced by the platform theors demand.

I submit the cavern phase of the argument to be one that is relevant, cogent, and obrious.

ToRquay.

H. J. Low. 